\title{
2 相サーボモータの等価回路定数の一算定法
}

\author{
篠宮栄*・岡田昌 丈* \\ A Method to Determine the Equivalent Circuit \\ Parameters of a 2-Phase Servomotor \\ Sakae ShinomiYA* and Yoshitomo OKadA*
}

It is well known that various performance. characteristics of a 2-phase servomotor can be investigated by using its equivalent circuit parameters.

In this paper, a method to determine the equivalent circuit parameters $\left(r_{1}, x_{m}, r_{2}, x_{1}\right)$ of 2-phase servomotor is described.

In this method, (1) $r_{1}$ is determined by measuring the $\mathrm{d}-\mathrm{c}$ resistance of the reference windings, (2) $x_{m}, r_{2}$ are determined by measuring both the maximum braking torque $\left[T_{o d}\right]_{\max }$ and the revolving velocity correspond to $\left[T_{o d}\right]_{\max }$, on the $\mathrm{d}-\mathrm{c}$ braking torque characteristics of 2-phase servomotor, (3) $x_{1}$ is determined by measuring the applied voltage, input current and the tuning current of the reference windings at zero speed.

To check the accuracy of this proposed method, the average torque and the alternating torque characteristics of the sampled 2-phase servomotor are calculated by using the equivalent circuit parameters which is determined by means of this method, and these calculated results are compared with the experimental ones.

The agreement is satisfactory, and this method was found useful.

\section{1. まえがき}

近年, 2 相サーボモータは制御要素として広く用い られているが，そのサーボモータの使用にあたって は, あらかじめサーボモータの動作特性を予知してお くことが望ましく，現に，2 相サーボモータのトル ク一速度特性 ${ }^{1)}$, 直流制動トルク特性 ${ }^{2), 3)}$, 交流制動卜 ルク特性 ${ }^{3)}$, 単相運転の判別 ${ }^{4)}$ 6), および電圧, 位相 不平衡時における電源周波数の 2 倍の振動トルク特

\footnotetext{
* 群馬大学工学部 桐生市天神町 1-5-1

* Faculty of Engineering, Gumma University, Kiryu (Received June 13, 1975)
}

性7),8)などがモータの等価回路定数を用いて容易に検 討できることが知られている. したがって，より信頼 度の高い検討結果を得るためには，その等価回路定数 をより正確に算定することが重要な要因の一つとな る.

従来, この等価回路定数の算定法に関しては, 松塚, 渡辺氏ら ${ }^{9)}$ が 2 相サーボモータの拘束拉よび無負荷試 験より入力インピーダンスとトルクを求め, てれらよ り等価回路定数を算定する方法を提案しており，その 後, 須藤, 横塚氏ら ${ }^{10)}$ が 2 相サーボモータの拘束時の 1 次入力と入力インピーダンス, および同期速度運転 時の入カインピーダンスをそれぞれ実測し，乙れらよ りインピーダンス比 $R / x_{0}, X / x_{0},\left(x_{0}=x_{m}+x_{1}\right)$ を 求め, 次いで前むって作成された $k$ (ステータ巻線に よる全磁束数とロータへの有効磁束数との比), $Q$ (モ ータの安定性を判別するための定数）とインピーダン ス比との関係図より, 上記インピーダンス比時の $k, Q$ を決定し，乙の $k, Q$ と 2 相サーボモータの等価回路 定数との関係より，その等価回路定数を算定する方法 を提案している. しかし，上記の算定法はいずれのむ のあ, その算定過程がきわめて複雑であり, 精度的に あ問題があるように思われる.

また，江尻氏 ${ }^{11) ~ 15) ~ は ~} 2$ 相サーボモータのトルク特性 を交さ磁界説に基づいて解析し，そのサーボモータの 一般的な特性式を導出するとともに，同式に基づいて 各種駆動条件下での 2 相サーボモータの振動トルク特 性の検討を行い，多くの貴重なる結果を報告してい る. しかし, 同報告では 2 相サーボモータの回路定数 を定数比の形で求める方法 (たとえば, $\tau=\omega L / R$ ) に ついての提案はなされているが，そのサーボモータの 等価回路定数の算定法に関しては述べられていない. ゆえに，従来はメーカなどによりサーボモータの設計 時に理論的に求められた等価回路定数を，必要に応じ て利用させてあらっているのが現状のようである.

しかしながら, この場合にも, 出力 $10 \mathrm{~W}$ 程度以下 
の小型のサーボモータになると, そのモータの磁気回 路が把握しにくくなるため，1次漏れリアクタンスや 励磁りアクタンスなどの等価回路定数の算定がきわめ て困難なものとなる傾向がみられる。

したがって，簡単な試験により，精度ある等価回路 定数が容易に算定できるような等価回路定数の算定法 が考案されれば，乙れは 2 相サーボモータの特性の解 析や検討を行ううえで，有用であると思われる.

そこで，筆者らはこのような立場に基づいて，幅広 く利用され，精度的にも十分満足できる 2 相サーボモ 一タの等価回路定数の算定法を考案するととを目的に 検討を行ってきた結果, 以下で詳述するような, 簡単 な試験により，精度ある等価回路定数を，容易に求め られることが明らかになったので，乙こにその適用例 ととあに報告するあのである．

\section{2. 等価回路定数の算定}

一般に，2 相サーボモータではその動作特性を検討 する場合，計算の簡易化のため，2 次漏れリアクタン ス $\left(x_{2}\right)$ や鉄損分等価抵抗などを，前者は 2 次抵抗 $\left(r_{2}\right)$ にくらべてかなり小さく，後者は励磁リアクタンス $\left(x_{m}\right)$ にくらべてかなり大きいという理由により，てれ らを無視して取扱っている場合（一般の市販のサーボ モータはこの場合に相当する，ただし，特殊設計のむ のにはむちろんての方式に修正を要する）が多い.

したがって，本文でもこれら 2 次漏れリアクタンス $\left(x_{2}\right)$ や鉄損などを無視した場合の等価回路定数の算定 法について以下述べるとととする.

\section{$2.1 r_{1}$ の算定}

1 次抵抗 $r_{1}$ は励磁巻線の直流抵抗を $\mathrm{DC}$ ブリッジ (たとえば,ホイートストンブリッジ) などを用いて実 湘することにより容易に求められる.

\section{$2.2 x_{m}, \boldsymbol{r}_{2}$ の算定}

励磁りアクタンス $x_{m}$ および 2 次抵抗 $r_{2}$ は 2 相サ 一ボモータの励磁巻線を直流励磁し，制御巻線を開放 した場合の直流制動トルク特性から最大制動トルク值

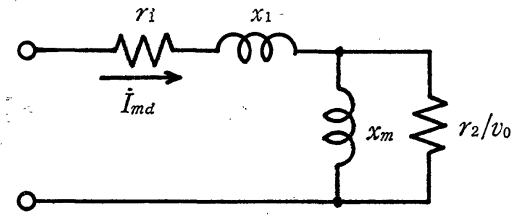

Fig. 1 Equivalent circuit for induction motor, where $V_{0}$ : revolving velocity $\omega_{0}$ per synchronous velocity $\omega_{s},\left|I_{m d}\right|=I_{0} / \sqrt{2}$ : equivalent a-c current (rms), $I_{0}:$ d-c exciting current
ならびにそのときの回 転速度を実測するとと により容易に求められ る.すなわち、このと きの制動トルク $T_{o d}$ は

Fig. 1 の等価回路を 参照してつぎのように 与えられる2),3).

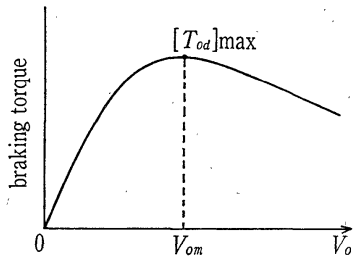

Fig. 2 Braking torque-speed characteristics of $2-$ phase servomotors

$$
\begin{aligned}
T_{\text {od }}= & \frac{10^{5}}{9.8(4 \pi f / P)} \\
& \cdot \frac{\left(I_{0} x_{m}\right)^{2}}{r_{2}}\left\{\frac{v_{0}}{1+\left(x_{m} / r_{2}\right)^{2} v_{0}^{2}}\right\} \text { 〔g-cm) }
\end{aligned}
$$

ここに, $P:$ モータの極数

$f:$ 等価回路定数設定時の電源周波数

ここで, (1) 式より極值条件 ${ }^{\prime}\left(d T_{o d} / d v_{0}\right)=0$ を求め, ると，制動トルクに最大值を生ずる速度

$$
v_{o m}=\frac{r_{2}}{x_{m}}
$$

制動トルクの最大值 $\left[T_{o d}\right]_{\max }$ は

$$
\left[T_{o d}\right]_{\max }=\frac{10^{5}}{9.8(4 \pi f / P)} \cdot \frac{I_{0}^{2} x_{m}}{2}[\mathrm{~g}-\mathrm{cm})
$$

となり (Fig. 2 参照), これら(2), (3)式より $x_{m}$, $r_{2}$ は次式により与えられる.

$$
\begin{aligned}
& \left.x_{m}=19.6 \times 10^{-5}\left(\frac{4 \pi f}{P}\right) \frac{\left[T_{o d}\right]_{\max }}{I_{0}^{2}} 〔 \Omega\right] \\
& \left.r_{2}=x_{m} \times v_{o m} 〔 \Omega\right]
\end{aligned}
$$

したがって，供試 2 相サーボモータの直流制動卜 ルク特性を実測し，その結果より最大制動トルク值 $\left[T_{o d}\right]_{\max }$ ，ならびに最大制動トルク時の速度 $v_{o m}$ を求 め，乙れらの值を上記 $(4),(5)$ 式に適用すれば，供 試 2 相サーボモータの $x_{m}, r_{2}$ は容易に求められる.

\section{$2.3 x_{1}$ の算定}

1 次漏れリアクタンス $x_{1}$ は停動時（励磁巻線 $\mathrm{AC}$ 励磁, 制御巻線開放)

の励磁巻線に対する印 加電圧，入力電流，お よび励磁巻線と並列に 同調用コンデンサを接 続した場合の入力電流 いわゆる同調電流を実 測することにより容易

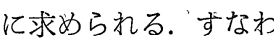
ち，2 相サーボモータ の停動時 $\left(v_{0}=0\right)$ の励 磁相等価回路はFig. 3 (a )で表わされるが,

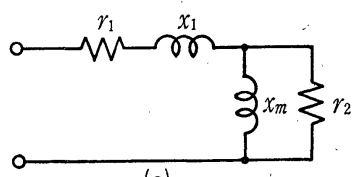

(a)

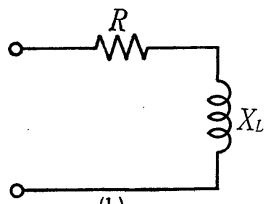

(b)

Fig. 3 Equivalent circuit for 2-phase servomotor at zero speed 
これを等価抵抗 $R$ ，および等価リアクタンス $X_{L}$ を用 いて Fig. 3(b) のように書き改めると，乙のときの 入力インピーダンス $\dot{Z}_{v_{0}=0}$, 位相角 $\varphi$ は

$$
\begin{aligned}
& \dot{Z}_{v_{0}=0}=R+j X_{L} \\
& \varphi=\tan ^{-1} \frac{X_{L}}{R}
\end{aligned}
$$

ことに

$$
\begin{aligned}
R & \equiv r_{1}+\frac{Q_{0} x_{m}}{1+Q_{0}^{2}} \\
& =\left|\dot{Z}_{v_{0}=0}\right| \cos \varphi \\
X_{L} & \equiv x_{1}+\frac{x_{m}}{1+Q_{0}^{2}} \\
& =\left|\dot{Z}_{v_{0}=0}\right| \sin \varphi \\
Q_{0} & \equiv \frac{x_{m}}{r_{2}}
\end{aligned}
$$

となり，上記 $(8),(9)$ 式より $x_{1}$ は次式により与えら れる.

$$
x_{1}=\frac{\left|\dot{Z}_{v_{0}=0}\right| \cdot\left(Q_{0} \sin \varphi-\cos \varphi\right)+r_{1}}{Q_{0}}
$$

他方，(10)式中の入力インピーダンスの大きさ $\left|\dot{Z}_{v_{0}=0}\right| や \sin \varphi, \cos \varphi$ などの項は, 停動時の励磁巻線 に対する印加電圧と入力電流, および Fig. 4 亿示す ように励磁巻線と並列に同調用コンデンサ $\left(C_{o}\right)$ を接 続し，とのときの入力電流，いわゆる同調電流を実測 するととにより，容易に知られる.

$\checkmark$ (i ) $\left|\dot{Z}_{v_{0}=0}\right|$ の場合: Fig. 4 において, $X_{c}=\infty$ と したときの印加電圧 $V_{m}$ とそのときの入力電流 $\left[I_{X_{c}}\right]_{\infty}$ の大きさを実测するととにより，次式より知られる.

$$
\left|\dot{Z}_{v_{0}=0}\right|=\frac{V_{m}}{\left[I_{X_{c}}\right]_{\infty}}
$$

(ii) $\cos \varphi, \sin \varphi$ の場合: Fig. 4 において, $X_{c}=$ $X_{C a}\left(=1 / \omega C_{0}\right)$ としたとき，すなわち同調時における 同調電流 $\left[I_{X c}\right]_{C o}$ を求めると

$$
\left[I_{X c}\right]_{C_{0}}=\frac{R V_{m}}{R^{2}+X_{L}^{2}}
$$

ここで, (12)式と上記(11)式との印加電圧 $V_{m}$ に着 目し，その両者を比較すると

$$
\left|\dot{Z}_{v_{0}=0}\right| \cdot\left[I_{X c}\right]_{\infty_{0}}=\frac{\left|\dot{Z}_{v_{0}=0}\right|^{2}}{R} \cdot\left[I_{X_{c}}\right]_{C_{o}}
$$

となり，とれより $\cos \varphi, \sin \varphi$ は次式により与えられ る.

$$
\begin{aligned}
\cos \varphi & =\frac{R}{\left|\dot{Z}_{v_{0}=0}\right|} \\
& =\frac{\left[I_{X_{c}}\right]_{C o}}{\left[I_{X_{c}}\right]_{\infty}} \\
\sin \varphi & =\frac{V \overline{\left[I_{X_{c}}\right]_{\infty}{ }^{2}-\left[I_{X_{c}}\right]_{c_{o}}{ }^{2}}}{\left[I_{X_{c}}\right]_{\infty}}
\end{aligned}
$$

そてで，上記(11)，(14)，(15)式の関係を前記(10)式 に適用すると， $x_{1}$ の算定式はつぎのように書き改め られる.

したがって,Fig. 4 亿示すような構成のもとに, 停動 時の励磁巻線に対する印加電圧 $V_{m}$, 入力電流 $\left[I_{X} c\right]_{\infty}$, 同調電流 $\left[I_{X c}\right]_{C_{o}}$ などを実測し，とれらの值と前記の $r_{1}, Q_{0}$ の值を上記(16)式に適用すれば，供試 2 相サー ボモータの $x_{1}$ は容易に求められる.

\section{3. 適 用 例}

ここでは，平衡巻線をもつ2機種 $(\mathrm{A}, \mathrm{B})$ の供試 2 相サーボモータについての適用例を示す. ここで取扱 う 2 相サーボモータの仕様はつぎのとおりである.

$\mathrm{A}$ 機: 出力 $3 \mathrm{~W}$, 相極数 2 相 2 極, 電源周波数

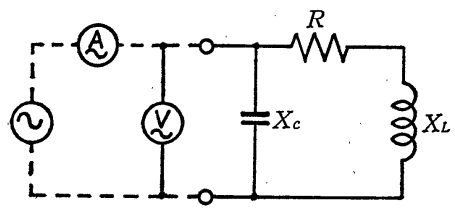

Fig. 4

Equivalent circuit for

2-phase servomotors

under the tuning condition
$50 \mathrm{~Hz}$, 励磁, 制御相定格電圧 $100 \mathrm{~V}$, 励磁, 制御巻線 の運転時 定格電流 $120 \mathrm{~mA}$

$\mathrm{B}$ 機: 出力 6 $\mathrm{W}$, 相極 数 2 相 2 極, 電源 周波数 50 $\mathrm{Hz}$, 励 磁，制御 相定格電 圧 $100 \mathrm{~V}$, 励磁, 制 御巻線の 運転時定
Fig. 5] Braking torque-speed characteristics of 2phase servomotors 
格電流 $155 \mathrm{~mA}$

\section{1 測定事項ならびに測定結果}

\section{(i) 1 次抵抗 $r_{1}$ の測定}

A機: $r_{1}=133.8 \Omega$

$\mathrm{B}$ 機: $r_{1}=101.4 \Omega$

（ii）直流制動トルク特性を実測し，これより最大 制動トルク $\left[T_{o d}\right]_{\max }$, および最大制動トルク時の回 転速度 $v_{o m}$ を求める. その実測結果は Fig.5 亿示す ようであり，[T od $]_{\max }, v_{o m}$ はそれぞれつぎのとおり であった。

$\mathrm{A}$ 機 $\left(I_{0}=120 \mathrm{~mA}\right)$ :

$\left[T_{o d}\right]_{\max }=202 \mathrm{~g}-\mathrm{cm}, v_{o m}=1.10$

$\mathrm{B}$ 機 $\left(I_{0}=155 \mathrm{~mA}\right)$ :

$\left[T_{o d}\right]_{\max }=278 \mathrm{~g}-\mathrm{cm}, v_{o m}=0.78$

（iii） 停動時の励磁巻線に対する印加電庄 $V_{m}$ とそ のときの入力電流 $\left[I_{X} c\right]_{\infty}$, および同調電流 $\left[I_{X c}\right]_{C o}$ を測定する，その結果はつぎのとおりであった。

$\mathrm{A}$ 機 $\left(V_{m}=81.8 \mathrm{~V}\right)$ :

$$
\left[I_{X c}\right]_{\infty}=120 \mathrm{~mA},\left[I_{X}\right]_{C_{o}}=85.8 \mathrm{~mA}
$$

$\mathrm{B}$ 機 $\left(V_{m}=77.0 \mathrm{~V}\right)$ :

$$
\left[I_{X c}\right]_{\infty}=155 \mathrm{~mA},\left[I_{X c}\right]_{C_{0}}=120.8 \mathrm{~mA}
$$

ただし，てのときの印加電圧 $V_{m}$ は磁気回路の飽和 などを考慮し， $\left[I_{X c}\right]_{\infty}$ が運転時の定格入力電流值と 同じになるように設定した.

なお，供試モータの測定時温度はいずれの場合に む, $60^{\circ} \mathrm{C}$ (モータの通常使用時温度) 一定に保った.

\section{2 等価回路定数の算定}

上記の測定結果を前記(4), (5), (16)式に適用し， 供試 2 相サーボモータの等価回路定数を求める, 之, $r_{1}, x_{m}, r_{2}, x_{1}$ などはそれぞれ，つぎのように与えられ る.

$\mathrm{A}$ 機の場合

(i) $r_{1}=133.8 \Omega$

(ii) $x_{m}, r_{2}$ は (4), (5)式より

$$
\begin{aligned}
x_{m} & =19.6 \times 10^{-3} \pi \times 202 / 0.12^{2} \\
& =863.3 \Omega \\
r_{2} & =863.3 \times 1.10=949.6 \Omega
\end{aligned}
$$

(iii) $x_{1}$ は(16)式より

$$
\begin{aligned}
x_{1}= & \left\{81.8 \times 10^{-2}(7.627-8.580)+1.927\right\} / 1.31 \\
& \times 10^{-2} \\
= & 87.6 \Omega
\end{aligned}
$$

$\mathrm{B}$ 機の場合

$\mathrm{A}$ 機の場合と同様にして各等価回路定数を求める

\begin{tabular}{|c|c|c|c|c|}
\hline $\begin{array}{ll}\text { sample } \Omega & \Omega\end{array}$ & $r_{1}$ & $x_{1}$ & $x_{m}$ & $r_{2}$ \\
\hline $\mathrm{A}$ & $\begin{array}{l}134 \\
(132)\end{array}$ & ${ }^{87.6}$ & $\begin{array}{c}863 \\
(793)\end{array}$ & $\begin{array}{c}950 \\
(938)\end{array}$ \\
\hline B & $\begin{array}{c}101 \\
(117)\end{array}$ & $\begin{array}{l}99.8 \\
(104)\end{array}$ & $\begin{array}{c}712 \\
(690)\end{array}$ & $\begin{array}{c}527 \\
(517)\end{array}$ \\
\hline
\end{tabular}
と，それらはつぎのように与えられる.
(i) $r_{1}=101.4 \Omega$
(ii) $\quad x_{m}=712.1 \Omega, \quad r_{2}=526.9 \Omega$

Table 1 Equivalent circuit parameters which is determinated by means of this determinating method, where $f=50 \mathrm{~Hz}$, Temp: $60^{\circ} \mathrm{C}$

(iii) $x_{1}=99.8 \Omega$

Table 1 は上記の等価回路定数の算定結果をまとめ て表にして，示したすのである．同表中（）内の值 は設計時に理論的に求められた等価回路定数を参考の ために示したあのであるが，い゙ずれの場合にも，両者 間にはかなり良い一致が認められる。なお，供試機 $\mathrm{A}$ の $x_{1}$ の場合にはその值が設計值のほうが比較的大き な值を示しているが，乙れは小出力，小型の 2 相サー ボモータになると，スロットやコイル端部などにおけ る漏れリアクタンスが理論的に把握しにくくなるた め，てのような現象が生じてきたあのと考えられる.

\section{2 相サーボモータの平均トルクおよび 振動トルク特性の計算結果亡実験結果 の比較}

ここでは供試機 $A, B$ の 2 機種について前節 3 で求 めた等価回路定数（Table 1 参照）を使用して, (4.1) では平衡 2 相電圧印加時のトルクースピード特性, (4.2) では不平衡 2 相電圧印加時における振動トルク 特性をそれぞれ計算し，その計算結果と実験結果とを 比較して示した.

なお，図中では本 方法により求めら れた等価回路定数 を用いて計算され た結果を実線，実 験值を点線，そし て設計時に求めら れた等価回路定数 を用いて計算され た結果を参考のた めに 1 点破線で示 した.

\section{1 平衡 2 相} 電圧印加 時のトル クースピ

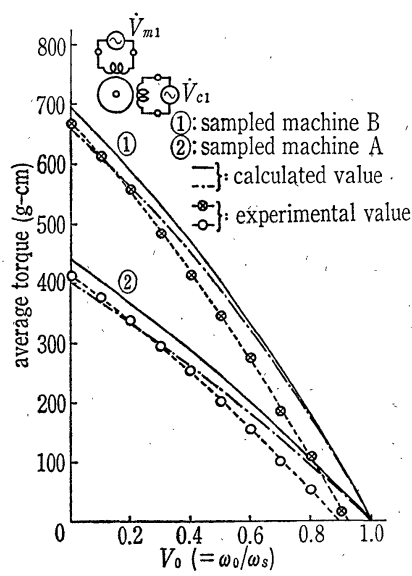

Fig. 6 Comparison of the calculated and experimental values, where $V_{m_{1}}=V_{c}=$ $100 \mathrm{~V}, f=50 \mathrm{~Hz}$ 
ード特性

2 相サーボモータの平衡 2 相電压印加時の平均ト
ปルク $T_{0}$ は次式で与えられることが知られている11 7).

$$
T_{0}=\frac{2 \times 10^{5}}{9.8(4 \pi f / P)} \cdot \frac{\left(x_{m} V_{m 1}\right)^{2}\left\{r_{2} /\left(1-v_{0}\right)\right\}}{\left\{r_{1} r_{2} /\left(1-v_{0}\right)-x_{1} x_{m}\right\}^{2}+\left\{r_{1} x_{m}+\left(x_{1}+x_{m}\right) r_{2} /\left(1-v_{0}\right)\right\}^{2}} \text { 〔g-cm] }
$$

したがって，上記(17)式より各供試機のトルクース ピード特性を計算し，ての計算結果とトルク計を用い て実測された結果とを比較すると Fig. 6 亿示すよう になり，いずれの場合む計算結果之実験結果とはかな りょく一致していることがわかる.

\section{2 不平衡 2 相電圧印加時の振動トルク特性}

2 相サーボモータの不平衡 2 相電圧印加時におけノ
】る電源周波数の 2 倍の周波数の振動卜ルク $T_{v}$ は等 価回路定数を用いて次式で与えられることが知られて (いる7).

$$
\begin{aligned}
T_{v}= & \frac{10^{5}}{9.8(4 \pi f / P)} \cdot V_{m 2^{2} C_{o}(v)\left(1-K^{2}\right)} \\
& \times v_{0} \cos 2 \omega t \quad[\mathrm{~g}-\mathrm{cm})
\end{aligned}
$$

$$
\begin{aligned}
C_{0}(v)= & \frac{x_{m}^{2}}{r_{2}} \sqrt{\frac{\left\{r_{2} /\left(1-v_{0}\right)\right\}^{2}}{\left\{r_{1} r_{2} /\left(1-v_{0}\right)-x_{1} x_{m}\right\}^{2}+\left\{\left(x_{1}+x_{m}\right) r_{2} /\left(1-v_{0}\right)+r_{1} x_{m}\right\}^{2}}} \\
& \times \sqrt{\frac{\left\{r_{2} /\left(1+v_{0}\right)\right\}^{2}}{\left\{r_{1} r_{2} /\left(1+v_{0}\right)-x_{1} x_{m}\right\}^{2}+\left\{\left(x_{1}+x_{m}\right) r_{2} /\left(1+v_{0}\right)+r_{1} x_{m}\right\}^{2}}}
\end{aligned}
$$

$$
K \equiv \frac{V_{c 2}}{V_{m 2}}
$$

$V_{m 2}, V_{c 2}$ : 励磁, 制御巻線の印加電圧

したがって, 上記(18)式より各供試機の振動トルク $T_{v}$ の大きさを計算し，乙の計算結果と加速度計 ${ }^{16)}$ 用いて実測された結果とを比較すると, Fig. 7 亿示 すようになり，いずれの場合も計算結果と実験結果之 はかなり良く一致していることがわかる。

以上の計算結果と実験結果との比較により, 本等価 回路定数の算定法が妥当なものであるととが判明し た.

\section{5.むすび}

本文では, 2 相サーボモータの等価回路定数 $r_{1}, x_{m}$, $r_{2}, x_{1}$ を簡単な試験により, 実験的に求める方法にノ

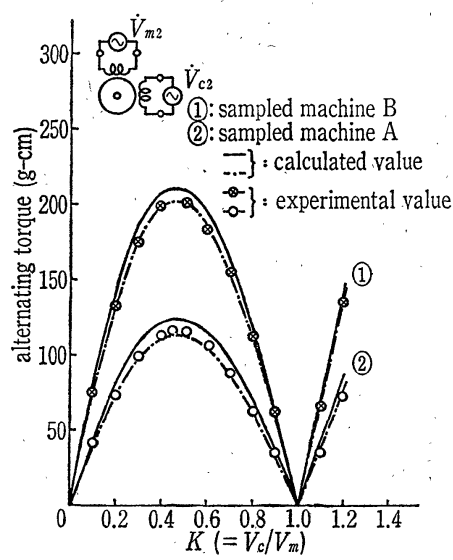

Fig. 7 Comparison of the calculated and experimental values, where $V_{m_{2}}=100 \mathrm{~V}$, $V_{c 2}=0 \quad 120 \mathrm{~V}$, $f=50 \mathrm{~Hz}$

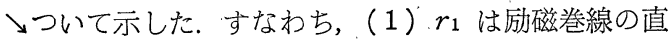
流抵抗を DC ブリッジなどを用いて実測する。（2） $x_{m}, r_{2}$ 注励磁巻線を直流励磁し，制御巻線を開放した 場合の 2 相サーボモータの直流制動トルク特性から最 大制動トルク值，ならびにそのときの回転速度を実測 する. (3) $x_{1}$ は停動時の励磁巻線汇対する印加電圧, 入力電流，および励磁巻線と並列に同調用コンデンサ を接続した場合の同調電流を実測するなどにより， それぞれの等価回路定数が容易に求められることを明 らかにした．次いで，本等価回路定数の算定法を適用 し, 出力 $3 \mathrm{~W}, 6 \mathrm{~W}$ の 2 機種の供試機について, そ の等価回路定数を算定し，乙の求められた定数を用い て, 供試機の平均トルクと振動トルク特性の計算を行 い，その実験結果と比較した．その結果，いずれの場 合も両者間にはかなり良い一致が示されて招り，本等 価回路定数の算定法が妥当なあのであるてとが確めら れた。

最後に，種々で教示くださった群馬大学の須藤二全 教授に深く感謝の意を表します。

\section{参 考 文 献}

1) A.E. Fitzgerald and C. Kingsley: Electric Machinery, p. 528, McGraw-Hill

2）須藤，横塚，篠宮; '町田：誘導機の直流制動飞関する解 析, 昭 41 電連大 424

3）横塚：かで形誘導電動機の制動特性，計測自動制御学会 論文集，5-5, 82/88 (1969)

4) A. Diamond: Effect of Driving Source Impedance on , Motor Performance, AIEE, Appl, \& Ind. No. $40,529 / 531$ (1959)

5）沼倉：2相サーボモータの伝達関数，計測と制御，1-1, 
$36 / 42$ (1965)

6) 須藤，篠宮：ゼロ制御電圧時における 2 相サーボモータ の発生トルクとダンピング係数の検討, 計測と制御, 8$10,695 / 700$ (1969)

7) 須藤, 戸恒：2 相サーボモータの振動トルクの解析, 計 测自動制御学会論文集，7-2，106/112 (1971)

8）須藤, 戸恒, 篠宮：2 相サーボモータの位相制御時にお ける振動トルクの解析, 計測自動制御学会論文集, 8-1, 96/103 (1972)

9）松塚, 渡辺：2 相サーボモータの等価回路の決定, 昭 35 年電気学会東京支部大会 40 (1960)

10) 須藤, 横塚: 2 相サーボモータの等価回路定数の求め方 およびその検討, 計測自動制御学会論文集, 3-2, 122/ 128 (1967)
11）江尻：2 相サーボモータの交さ磁界法による解析, 計測 自動制御学会論文集, 1-2, 63/74 (1965)

12）江尻：2相サーボモータのトルク変動と振動, 計測自動 制御学会論文集，1-2，189/198 (1965)

13）江尻：カサーボ機構における 2 相サーボモータの振動問 題, 計測と制御, 5-1, 3/11 (1966)

14）江尻：計器用キャリア形位置サーボ機構の微小振動，計 测之制御，5-11，780/790 (1966)

15）江尻：2相サーボモータのパラメトリック共振, 計測自 動制御学会論文集, 2-1, 53/62 (1966)

16) 須藤, 策宮, 戸恒, 梅沢：2 相誘導発電機形加速度計の 基礎特性の検討, 制御工学, 11-6, 18/23 (1967)

17）茂木：シンクロとサーボモータ，book，日刊工業新聞社 (1964) 